\title{
Human Rights and Expulsion: Giving Content to the Concept of Asylum
}

TOM CLARK*

\section{Abstract}

This paper explores the potential in granting asylum as a means of fulfilling a State's protection obligations. The nature and content of asylum are examined. Current practices for conferring refugee status under the 1951 Geneva Convention definition satisfy much of the nature and content of asylum granting. However, serious violations of obligations concerning the treatment of aliens on State territories occur, while questions of asylum or expulsion are being resolved. State treaty obligations concerning expulsion or transfer of persons to another State are examined. These obligations are met for the majority, but failure to honour obligations before expulsion for some people results in on-going violations of key human rights. Asylum is compared with other State responses to the obligations that qualify or condition the power of expulsion. The paper suggests potential benefits that would flow from clarity and greater coherence of asylum granting, using the particular situations of Canada and the United States to illustrate the role which asylum could play.

\section{The Nature and Content of the Right to Asylum}

The right to seek and enjoy asylum was declared in the Universal Declaration of Human Rights and, with a little more force, in the American Declaration of Rights and Duties of Man.' Surprisingly, the right can be realized in many countries, but with variations. In a recent UN report, Special Rapporteur Mubanga-Chipoya reports

- Coordinator, Inter Church Committee for Refugees, Toronto, Ont., Canada. The opinions in this paper are the personal views of the author and do not reflect policy positions of the Canadian churches.

1 The Statute of the Inter-American Commission on Human Rights declares that 'human rights are ... in the American Declaration'. The OAS Charter provides that the Commission's 'principle function shall be to promote the observance and protection of human rights'. 
that asylum consists of several elements: to admit a person to the territory of the State, to allow the person to remain there, to refuse to expel, to refuse to extradite and not to prosecute, punish or otherwise restrict the person's liberty. ${ }^{2}$ This paper focuses mainly on those who are already on the territory of a State where the distinctive element of the right to asylum is the right to remain.

\section{The 1951 Geneva Convention and Asylum Granting}

In a paper which favours a restricted refugee definition, Martin argues that the 1951 Geneva Convention and 1967 Protocol do not grant a right to asylum. ${ }^{3}$ I agree the Convention gives no right to asylum; however, the Convention and its definition have become an international norm for granting the right to asylum, as defined above. Canada and the United States have a domestic legal procedure in which the right to remain, asylum, is granted to persons deemed to satisfy the definition of refugee in the 1951 Geneva Convention. Asylum granting can be explicit or implicit, and the procedure involves case by case examination and decision-making by a quasijudicial and quasi-independent tribunal. In accordance with article 33 of the 1951 Geneva Convention, the consequence of refugee status protects the person from transfer to the country, in which the person faces a threat to life or freedom. This approach is also characteristic of European countries, for example France and Germany.

The asylum granted under the 1951 Convention is usually a special form. The right to remain is generally permanent for those who meet the Convention refugee definition. In Canada and the United States persons granted asylum can almost invariably proceed to permanent resident status. From this status, they can attain citizenship. In Canada, citizenship does not require denial of previous citizenship, so that the right to return to a home country at some future date is protected.

Asylum under the 1951 Convention need not lead to the right to remain permanently on the territory of the State granting the asylum. The screening procedures of the United Nations Comprehensive Plan of Action ${ }^{4}$ satisfy much of the nature and content of asylum. In this

\footnotetext{
${ }^{2}$ Mubanga-Chipoya, C.L.C., Final Report, The Right of Everpone to Leave any Country, Induding His Own, and to Rewm to His Counto. UN doc. E/C.4/Sub.2/1988/35, June 1988, pp. 103-6.

3 Martin, D., "The Refugee Concept: on Deportations, Politics and the Careful Use of a Scarce Resource,' in Adelman, H., (ed.), Refugee Polig: Canada and the United States, York Lanes Press, 1991, pp. 30-51.

${ }^{4}$ International Conference on Indo-Chinese Refugees, 13-14 June 1989, Declaration and Comprehensive Plan of Action, Section D, Refugee Stalus. For text, see UN doc. A/CONF.148/2 (26 Apr. 1989); 1 IJRL 574 (1989).
} 
situation, States such as Hong Kong and Malaysia make the decision which grants asylum with prior agreement that persons who are 'screened in' by the application of the Convention refugee definition will proceed to permanent resident status in a third country, such as Canada or the United States. By prior international agreement, asylum decisions made in one country can result in the right to remain in another. Under the UN Comprehensive Plan, asylum seekers voluntarily proceed to resettlement in one of the third countries, while these countries retain some control over who is given the right to enter and remain, namely, asylum.

The protection of persons through asylum based on the 1951 Geneva Convention is inadequate in practice. Application of the Convention definition varies and there is no international point at which its interpretation is co-ordinated. True, signatory States grant the United Nations High Commissioner for Refugees a supervisory role in the asylum procedure under article 35 of the 1951 Geneva Convention. However, the detailed roles which States allow the UNHCR also vary. Moreover, the UNHCR is a political inter-governmental agency with a variety of functions, and not equivalent to a body of independent experts with authority to interpret and apply the treaty, such as the UN Human Rights Committee or the Committee against Torture. As a consequence, in any particular State, the Convention refugee definition may or may not include some individuals and groups whom the State has an obligation to protect. In addition, the procedural safeguards for applying the Convention definition have questionable status and are defined in broad terms outside the body of the treaty. ${ }^{3}$ Practices vary considerably from State to State, and procedures can be protracted. Large numbers of asylum-seekers spend long periods of time under precarious and hurtful conditions with uncertain status, which may encourage migration to countries with less prejudicial asylum arrangements.

Asylum granting nevertheless has advantages for the State. Stringent procedural safeguards are required when the expulsion of any non-national is contemplated. If expulsion is not even implicitly at issue, asylum granting requires fewer procedural safeguards. If States intend to honour other treaty obligations not to expel some individuals and some classes of persons, it could be advantageous to clarify the definition used to grant asylum so as to include them. These obligations relate to the protection of the human rights of all non-nationals, including asylum seekers, on a State's territory; the protection of human rights in the expulsion or transfer to another State of certain

5 UN GAOR, 32nd Sess., Supp. No 12: A/32/12/Add.1, para. 53(6)(c), (Dec. 1977). 
persons declined asylum; and procedures to grant asylum and protect other rights, that conform to international standards.

\section{Treatment of Non-Nationals}

The treatment of non-nationals on the territory of a State, including those in asylum procedures, is the subject of General Conclusions 15 of the UN Human Rights Committee. ${ }^{6}$ For signatory States to the UN Covenant on Civil and Political Rights, non-nationals enjoy the rights of 'everyone': 'Thus the general rule is that each one of the rights of the Covenant must be guaranteed without discrimination between citizens and aliens." Such rights include treatment by the asylum process itself. In this regard, the UN Human Rights Committee noted in its examination of Canada that there should be no discrimination in granting asylum and that long delays in resolving the status of traumatized asylum seekers could be a form of cruel treatment. ${ }^{8}$

The American Civil Liberties Union report, Detention of Undocumented Aliens, ${ }^{9}$ revealed the human impact of the immigration rule that requires detention of excludable aliens without proper entry documents and permits parole only when 'strictly in the public interest'. There is discrimination. Four fifths of detentions over thirty days were accounted for by only eight countries: 'the standards were envisaged for brief detention only'; and 'the standard was one thing, compliance was another'.

A 1989 discussion paper by the Canadian Council for Refugees on immigration detention reported related violations of rights in Canada. ${ }^{10}$ In contrast to the approximately 3,000 persons detained in the US, the paper estimates the number in Canada to be several hundred; and while detention in the United States may last several months, in Canada it is for several weeks. However, the Canadian paper reveals that there is often insufficient evidence to warrant detention and inappropriate reasons are given to justify it. Review and release practices are unjust and ineffective. Limited access to lawyers, legal costs, and difficult documentation requirements block the use of habeas corpus in all but a few isolated instances.

The Minority Rights Group, in evidence to the UN Commission on

\footnotetext{
6 International Covenant on Civil and Political Rights, Human Rights Committee, General Comment 15, The Position of Alums under the Coonant: UN doc. CCPR/C/21/Rev.I, 19 May 1989, p. 17.

7 Ibid., para. 2.

- Human Rights Committee, 40th Sess., Summary Record of 1013rd Mig., 24 Oct. 1990: UN doc. CCPR/C/SR.1013 (Nov. 1990).

${ }^{9}$ Detention of Undocumented Aliens, American Civil Liberties Union, Oct. 1990, pp. 6, 28, 30.

10 Problems on the Path to a Just Society: A Human Rights Analysis of Canada's Immigration Lowo and Practice, Canadian Council for Refugets, July 1989.
} 
Human Rights, referred to violations of rights in Europe, including incommunicado detention of asylum-seekers at ports of entry for substantial periods, detention on board ships, or in tented housing in subzero temperatures; and to instances of suicide. ${ }^{11}$ Despite the relatively generous provision of asylum at the purely numerical level, compliance with the Covenant on Civil and Political Rights is incomplete in several western countries, including Canada, at the level of international obligations, and the United States, at the level of international human rights standards.

Surprisingly, the Office of the UN High Commissioner for Refugees made little or no reference to such problems confronting asylum seekers in its Statement to the UN Commission on Human Rights. ${ }^{12}$ This is remarkable when the same office speaks to the High Commissioner's own Executive Committee about a range of immense socalled 'protection' problems facing refugees: aerial bombardment, military attacks, forcible recruitment, detention in circumstances outside accepted guidelines, lack of freedom of movement, property problems, travel document problems, denial of employment and others. ${ }^{13}$ One wonders why these evident human rights violations could not be presented as such to the UN Commission on Human Rights. Clearly, the treatment of non-nationals is an area of persistent, serious and systematic human rights violations on a world scale. Yet only in the UN Human Rights Committee does there seem to be a United Nations effort to begin to respond to this international problem.

Some violations and departures from standards in Canada and the United States are surprising because domestic law offers the basis for an expansive interpretation of civil rights. If one accepts the judgments of the Canadian ${ }^{14}$ and US Supreme Courts, ${ }^{15}$ the rights to security of the person (Canada) and the right to liberty (United States) can each encompass rights to meaningful work and to some protection from destitution, as well as freedom of movement and the right to enjoy family life.

Certain special rights under the Covenant on Civil and Political Rights, such as article 13, apply to non-citizens. ${ }^{16}$ This grants the

\footnotetext{
"Commission on Human Rights, 47th Sess., Summary Record of 28ch Mtg. UN doc. E/CN.4/1991/SR.28, Feb. 1991, pp. 15f.

12 Statement by Michel Moussalli, Director of International Protection, UNHCR, 47th Sess., UN Commission on Human Rights, 26 Feb. 1991.

13 UNHCR, Note on Intemational Protection: UN doc. A/AC.96/750, Aug. 1990.

${ }^{14}$ Singh at al o. Minister of Employment and Immigration [1985] SCR 117

13 Board of Regents of State Colleges 0 . Roth 408 U.S. 564,572 (1972) refers to liberty in the Fourteenth Amendment: 'Without doubt, it denotes not merely freedom from bodily restraint but also the right of the individual to contract, to engage in any of the common occupations of life, to acquire useful knowledge, to marry, establish a home and bring up children, to worship God according to the dictates of his own conscience...'

${ }^{16}$ See General Conclusions 15, above note 6, para. 10.
} 
right to present reasons to competent authorities prior to expulsion. The UN Human Rights Committee has explained that 'expulsion' means all forms of removal, and can include situations in which the legality of a non-citizen's entry is at issue. Not only is the hearing required, but the Committee has stated that, 'An alien must be given full facilities for pursuing his remedy against expulsion so that his right will in all circumstances be an effective one.' This has implications for both asylum and for the procedural requirements relating to other obligations not to expel. ${ }^{17}$ If the asylum process involves an examination of the legality of entry, and expulsion is the implicit consequence of failure in the asylum process, then the Covenant requires a hearing and 'full facilities for pursuing his remedy against expulsion...' Under the Canadian Immigration Act, a rejected asylum-seeker may seek leave to apply for judicial review. Other nonnationals in Canada have access to the Immigration Appeal Division of the Immigration and Refugee Board, and thereafter may seek leave to apply for judicial review. The asylum-seeker's more restricted appeal rights do not appear to conform with the said 'full facilities', and may constitute discrimination within the meaning of Covenant article 26 .

In summary, obligations for the treatment of non-nationals are generally clear. There are compliance mechanisms through the UN Commission on Human Rights and through the UN Committee on Human Rights. True, full compliance is yet to be achieved. This may be because the various human rights treaty bodies have been reluctant to enter an area of confused jurisdiction. The right to asylum does not exist in the human rights treaties, and the 1951 Convention is the responsibility of the UNHCR. But governments have agreed on basic principles and mechanisms, and further international agreement to clarify and accelerate asylum granting would itself lead to reduction in the scope for the pervasive human rights violations noted above.

\section{Prohibitions on Expulsions or Transfers of Persons to another State}

States have no explicit international authorization to expel persons to another State against their wishes. The individual has an unambiguous declared human right to return to his or her country of nationality, ${ }^{18}$ and a State has an implicit right to expel a national to their country of citizenship, inherent in the general concept of

\footnotetext{
17 The Committee also expressed the view that Covenant article 14(1) was applicable in the case of $x \times x \quad v$. Canada, and that in the circumstances an independent and impartial tribunal was required to hear the reasons against expulsion under Covenant article 13.

is 1948 Universal Declaration of Human Rights, art. 13(2).
} 
sovereignty. However, 'sovereignty does not signify unbridled freedom, but rather is an attribute of equality between States and is subject to the duty to comply faithfully with international obligations. ${ }^{19}$ Limits or prohibitions on expulsion have been set by international agreement. The clearest is the prohibition on expelling a person to a country where their life or freedom may be threatened. There are also limits on a receiving State's right to deny entry. ${ }^{20}$

It is not clear, however, that a State is invariably obliged to allow the entry of a person forcibly returned or expelled, even if the person is a national. If the receiving State is willing but unable to guarantee the most basic human rights of a returning national, that State's human rights obligations would be breached by receiving the person. There is thus a basis for denying entry. Looked at another way, if the sending State is not following the principles and policies of the UN in expelling the person, the receiving State has a basis for not allowing admission. Perhaps for these reasons, there is some evidence that return of significant numbers of nationals requires a specific international agreement. Under the UN Comprehensive Plan of Action, Viet Nam at first gave notice that it would only accept back those nationals who voluntarily returned or who did not object to being returned. In 1991, with an agreement to provide some financial assistance, Vietnam agreed to take back Vietnamese nationals who did not volunteer to return from Hong Kong.

Some multilateral treaties explicitly provide for the transfer of persons between States. Clearly, transfer is a form of expulsion so that any involuntary transfer of a non-national can only be made after hearing reasons and giving full facilities for pursuing a remedy, described above. Subject to these conditions, the State signatory to the 1949 Fourth Geneva Convention has the right to transfer a civilian national from another State party to a conflict under article 45. However, the transfer must be made to a State willing and able to fulfil its obligations under the treaty, which may be difficult in practice. ${ }^{21}$ Nonetheless, the 'prohibition' gives a principle for transfer of persons to another State. A State might argue that a parallel implicit authorization exists to transfer asylum-seekers to signatory States of the 1951 Geneva Convention which are willing and able to fulfil their

19 Patrnogic, J., 'Inter-Relationship Between General Principles of International Law and Fundamental Humanitarian Principles Applicable to the Protection of Refugees,' Annales de Droil Intemational Medical, 1977.

${ }^{20}$ See General Conclusions 15, above note 6, para. 5: 'However ... an alien may enjoy the protection of the Covenant even in relation to entry or residence, for example, when considerations of non-discrimination, prohibition of inhuman treatment and respect for family life arise.'

21 This is a difficult test to apply in practice, because obligations under the Fourth Geneva Convention are numerous and detailed and some are almost certain to be broken in part. Also, the International Committee of the Red Cross which is responsible for overseeing application of the Convention, does not generally declare whether a State is or is not in compliance. 
obligations. However, the obligations are unclear. Even the Convention refugee definition is variably interpreted and there is no competent independent arbitrator. Thus, even this parallel argument cannot form a basis for involuntary transfer. It does, however, point to the potential value of harmonizing asylum granting procedures among governments desiring to transfer persons.

Return of inadmissible persons is also provided for in a recent amendment to the Standard under the International Civil Aviation Organization. ${ }^{22}$ The Standard explicitly limits return, however, and requires examination of the person concerned. Return is prohibited if the person is an asylum-seeker and life or freedom would be threatened. Also, a State would need to contend with its obligation to treat asylum-seekers equally no matter their mode of transportation.

Limits or prohibitions on any form of expulsion or transfer of persons from one State to another stem from two sources. These would form the 'reasons' in the required expulsion hearing under Covenant article 13. There are obligations under human rights treaties to anticipate violations of non-derogable rights as a consequence of return; these include rights related to freedom from torture, and the right to life, liberty and security of the person, non-discrimination, a fair trial and protection of the family. ${ }^{23}$ This has been referred to by Einarsen who sees obligations under the European Convention as amounting to a right to de facto asylum. ${ }^{24}$

Obligations also apply with respect to civilian nationals from a State experiencing an internationally recognised civil conflict who are present on territory controlled by another State signatory to the treaties. ${ }^{25}$

An explicit obligation against return is found in article 3 of the 1984

${ }^{2}$ International Civil Aviation Organization, Facilitation Division - Tenth Session, Montréal, Sept. 1988, 'Return of Inadmissible Persons' Standard A: 3.35.1: 'Contracting States shall accept for examination a person being returned from his point of disembarkation after having been found inadmissible if this person previously stayed in their territory before embarkation, other than in direct transit. Contracting States shall not return such a person to the country where he was earlier found to be inadmissible.' Note 2 provides: 'Nothing in this Standard or in Note 1 is to be construed so as to allow the return of a person secking asylum on the territory of a Contracting State to a country where his life or freedom would be threatened on account of his race, religion, nationality, membership of a particular social group or political opinion.' Cf. Feller, E., 'Carrier Sanctions and International Law,' I JJRL 48, 65 (1989).

${ }^{25}$ Clark, et al, 'Protection of Human Rights in All Forms of State Act of Return,' Discussion Paper, Canadian Council for Refugees, 1989, pp. 8-10. Cf. UN Human Rights Committee, Interlocutory Decision 22/1977, 26 Jul. 1978: "the committee is of the view ... that the alleged victim, having sought refuge in S, should not be handed over or expelled to country $X$.' See also the Soering case, Judgment of the European Court on Human Rights, (1989).

${ }^{24}$ Einarsen, T., 'The European Convention on Human Rights and the Notion of an Implied Righe to De Facto Asylum,' 2 lJRL $361-89$ (1990).

is Matas, D., 'Innocent Victims of War as Refugees,' Obligations and Their Limits, Conference Papers, Vol. 1, p. 127, May 1991, Centre for Refugee Studies, York University; Clark, T., 'Obligations concerning Nationals to a State Party to an Internationally Recognized Armed Conflict,' ibid., p. 165. 
Convention against Torture and other Cruel, Inhuman or Degrading Treatment: 'No State shall expel, return (refouler) or extradite a person to another State where there are substantial grounds for believing that the person would be in danger of being subjected to torture.' Competent authorities are obligated to take into account all relevant information including a consistent pattern of gross, flagrant or mass violations of human rights. Such obligations have been recognized by the UN Human Rights Committee under the Covenant on Civil and Political Rights, by the European Commission on Human Rights and by the European Court on Human Rights.

The second source of obligations are the treaties governing the treatment of civilians who fall under the power of another State in time of war or civil strife. If party to the conflict, a signatory State has an explicit obligation not to transfer civilians under its jurisdiction to another State unless that State is both willing and able to uphold the Geneva Conventions of 11 August 1949 (and, for signatories, Protocol II thereto.) According to the introduction to the Fourth Convention, this obligation is intended to ensure that even in the midst of hostilities, the dignity of the human person shall be respected. This requires at least determining whether the State is willing and able to ensure the basic human rights spelled out in common article 3 of the Conventions and in the articles of Protocol II if applicable. The obligations link to peacetime obligations in several ways. First, protection of civilians is the evident purpose of the Fourth Convention and Protocol II. Second, the Convention requires signatories to honour its provisions 'in all circumstances', which extends to the treatment of civilian nationals on their territory who come from a State party to a recognized conflict. Third, States are under greater obligation to grant rights in time of peace than in times such as war, which can otherwise be the basis for derogation of some rights. Fourth, States must treat persons equally with respect to non-derogable rights irrespective of whether their State is a party to a conflict or not.

These obligations are for the larger part upheld in many countries, though the means used vary significantly in the Western world. Several European States make provision for de facto refugees or humanitarian cases. Other States simply allow rejected asylumseekers to remain by not deporting them. ${ }^{26}$ They can join the underground economy but live in legal limbo.

\footnotetext{
${ }^{26}$ See Hathaway, J., The Lazo of Refugee Slatus, Butterworths, 1991, pp. 21-7. Hathaway refers to Hailbronner, K., 'Non-Refoulement and 'Humanitarian' Refugees: Customary International Law or Wishful Thinking?' 26 Virg. J. Int. L. 857, 887 (1986), and Goodwin-Gill, G.S., ibid., 897-918, who argues that, as a matter of customary international law, refuge is owed to a broader class of refugees than that defined in the 1951 Convention. For present purposes, it suffices to note that other authors confirm the State practice of allowing a majority of asylumseckers to remain.
} 
United States law now provides for Temporary Protected Status (TPS), ${ }^{27}$ which allows nationals from named States to remain for a renewable term, on the basis of civil conflict. In addition, U.S. law provides a hearing for individuals prior to deportation, ${ }^{28}$ and declares that 'the Attorney General shall not deport or return any alien . . . to a country if . . . such alien's life or freedom would be threatened ... on account of race, religion ...' Although in theory this hearing could be interpreted to withhold deportation in accordance with international human rights obligations, the Courts have required a standard of proof which severely limits the protection available in practice. The United States largely tolerates the significant population of noncitizens, including some asylum-seekers, who are known to exist without formal status.

Section 3 of the Canadian Immigration Act 1976 recognizes the need 'to fulfil Canada's international legal obligations with respect to refugees and to uphold its humanitarian tradition with respect to the displaced and persecuted...' Section 114 allows the Governor-inCouncil to admit persons to Canada who would otherwise not satisfy the regulations, for compassionate or humanitarian considerations. At present, Canada recognizes as Convention refugees a significant fraction of the persons who seek asylum - between 60 and $70 \%$. However, an appropriate mechanism to implement the provisions for humanitarian and compassionate protection for those declined asylum is lacking. To comply with article 13 of the Covenant, a hearing of the reasons against expulsion is required, but there is no explicit protection in law or regulations. Employment and Immigration Canada guidelines allow rejected refugee claims to be reviewed by immigration officials on humanitarian and compassionate grounds. These grounds are intended to cover persons facing severe sanctions, family dependency, and persons who will suffer disproportionate hardship if returned. As noted above, such concerns relate to 'rights' which can prohibit expulsion under the Covenant and the Fourth Geneva Convention. In theory, such concerns could be read into the refugee definition. ${ }^{29}$ In practice, many of refused asylum applicants are not expelled unless they appear for departure.

Although international obligations are honoured for the most part

27 This is briefly outlined by Helton, A.C., 3 JJRL 125-6 (1991).

28 See Immigration and Nationality Act, s.243(h); 8 U.S.C. 1253 (h).

29 In its examination of Canada under article 40 of the Covenant on Civil and Political Rights in Oct. 1990, a member of the UN Human Rights Committee concluded that 'The 1951 Geneva Convention ... should be interpreted in a manner consonant with obligations under the Covenant'. This refers at least to the non-discrimination provisions. Similarly, the 1951 Convention must be applied in a manner consonant with the Fourth Geneva Convention and Protocol II which Canada has ratified. The effect of the 'consonance' on the application of the refugee definition is potentially far reaching. Unfortunately, the notion has not progressed into explicit criteria and guidelines. 
in many countries, the lesser part is a story of sporadic violations of basic human rights. During the summer of 1991, for example, Albanian asylum-seekers were turned back by Italy without examination of their claims. ${ }^{30}$ In October, a refugee hostel was set on fire in Germany in a racist incident. Haitian asylum-seekers have been forcibly returned by the United States through 1992. In late 1990 and early 1991, Canada also deported not only civilian nationals fleeing civil conflict, but also persons who belong to groups manifestly at risk, such as Sri Lankan Tamils.

Nearly all the present protective measures used by governments involve uncertainty for the persons involved - an uncertainty fanned by the few publicized deportations. This uncertainty is arguably a violation of the right to security of person and to mental health, and can amount to cruel treatment within the meaning of article 7 of the Covenant on Civil and Political Rights, especially if the person concerned has experienced some form of trauma. The prolonged separation from spouse and children is a violation of the right to protection of the family. In addition, people living under prolonged uncertainty and family separation form a potentially mobile group which can easily be provoked into moving on to an adjacent State. For example, the introduction of employer sanctions in the United States in 1986 coincided with an increased number of asylum claims in Canada.

When large numbers of persons are involved, the case by case asylum granting process may appear costly and the approach of the United States Temporary Protected Status attractive. However, the State offering temporary refuge has two particular obligations, the first of which is to treat persons equally. The UN Human Rights Committee has insisted that States take this obligation very seriously. The criteria for deciding which nationals receive temporary refuge must be entirely objective. For example, granting temporary refuge to nationals of countries identified by the UN for investigation of gross and systematic human rights violations may satisfy the objective standard requirement. Similarly, granting temporary refuge to persons from a conflict recognized by the International Committee of the Red Cross as within the Geneva Conventions may qualify. However, it is difficult for a State to argue it meets obligations to treat nonnationals without discrimination if those in temporary refuge have fewer substantive rights than other non-nationals, such as Convention refugees.

Secondly, there are the procedural obligations which attach to any decision on expulsion, and bear on the problem of how to end temporary refuge. If the State seeks involuntary return, that case by case

so See Nascimbene, B., "The Case of Albanians in Italy: Is the Right of Asylum under Attack?' 3 IJRL 714 (199I). 
examination will be required, which temporary refuge was to avoid. The work and social ties which develop and accrue over time constitute a form of 'security of the person' or a broadly interpreted form of 'liberty' in the country of temporary protection. The State desiring a delayed return must justify its deprivation of this acquired security of the person. One solution is to provide automatic recognition of de facto resident status after a reasonable period of time has elapsed. However, this would need to be substantially similar among States, if the risk of exodus from one State to another is to be minimized.

Thus the widespread practice of offering temporary asylum, either explicitly or as a consequence of protracted procedures, contains a number of difficulties. International agreement to clarify those who are to be protected would reduce the potential for human rights abuses.

\section{Procedural Obligations}

The UN Human Rights Committee has expressed its views on procedure in General Conclusions 15 on the position of aliens under the Govenant. They can be summarized as a hearing on the matters at issue in any form of expulsion, and an effective remedy. In Vilvarajah in 1991, the European Court of Human Rights indicated that an effective remedy must allow a superior court to review and overturn a decision on the asylum-seeker's case. ${ }^{31}$ The decision appears to fall short of the requirements reflected in the General Comment of the UN Human Rights Committee, to the effect that the remedy, in all the circumstances of the individual, must be an effective one. However, some combination of hearings and appeals must always constitute an effective remedy.

The Human Rights Committee has also endorsed 'the general rule' that each of the rights under the Covenant must be guaranteed without discrimination between citizens and aliens. Hence, it can be argued that if expulsion puts life or freedom at issue, the procedural safeguards which apply to a citizen threatened by deprivation of life or liberty should apply. This is the case, for example, in the most serious criminal charges, and applicable minimum procedural safeguards are set out in article 14(3) of the Covenant. One member of the Committee concluded Canada's examination under article 40 by noting that whether article 14 applied to administrative courts had not yet been resolved. It seemed that those courts were actually judicial bodies to which some, if not all, of the principles set out in article 14, such as independence and impartiality, should apply. Another Committee

31 Viloarajah et al 0 . United Kingdom, Judgment of the European Court of Human Rights, 30 Oct. 1991. 
member concluded that asylum-seekers should enjoy the rights recognized by the Covenant, even if the question of asylum was not mentioned in it. In her view, however, those questions did not come under articles 9 or 14 , or even 7 , of the Covenant, but rather under article 26 , which requires non-discrimination. The international position on this matter seems to be evolving, and the second report prepared in 1991 by Chernichenko and Treat on the right to a fair trial, concludes that 'Immigration hearings and deportation proceedings may be suits at law', and therefore require the independent and impartial tribunal of Covenant article $14 . .^{32}$

Administrative decision-making, without discrimination, can thus lead to positive determinations on asylum. The relatively independent bodies used by several countries to make decisions on refugee status come close to what is required, and if they respond to the majority of applicants, offer States a cost-effective process. Relatively swift procedures on clear criteria do not in general attract a large number of manifestly unfounded applicants. If the consequence of the decision is the expulsion of the person, however, then more stringent procedural safeguards are needed. Canada and the United States have different answers to these procedural questions.

Canada has a relatively simple quasi-judicial asylum granting tribunal, under which the majority of applicants currently receive asylum. But a negative decision can lead to expulsion, and there is no independent appeal on the merits and no point in the procedure for the formal examination of reasons against expulsion from rejected asylum-seekers. The asylum file is informally reviewed by immigration officials and the individuals concerned may petition the office of the Minister of Immigration. In theory, the individual may also seek a remedy if Canadian Charter rights are violated, but there are a number of practical obstacles, including little experience or training in this kind of litigation among lawyers, decision-makers and judges. At present, the court remedy is not a viable option.

In the United States, requests for withholding of deportation are decided in a formal legal process, which is commonly the next step after a negative asylum decision. The procedure has the potential to conform to the procedural standards of article 14, but it is not directed to examining all the relevant reasons against expulsion. Many human rights treaties, including the Covenant on Civil and Political Rights, remain unratified by the United States, and there is not the expectation, the training or the experience to examine all the international rights placed at risk by deportation. Also, one might have expected a

\footnotetext{
92 Second report by Chernichenko, S. and Treat, W., in accordance with resolution 1990/18 of the Sub-Commission and resolution 1991/43 of the Commission on Human Rights: UN doc. E/CN.4/Sub.2/1991/29 (Jul. 1991).
} 
relationship between temporary protected status and the provisions on withholding of deportation. To ensure non-discrimination, withholding of deportation procedure should allow individuals from civil conflicts which are substantially similar to those giving rise to group benefits under TPS, to benefit from similar protection.

\section{Conclusion: Towards a Better Way}

Clarifying the definition of refugee used to grant asylum in an unrestrictive manner would make it easier for States to meet procedural obligations and easier to transfer persons to other participating States with safety and dignity. Martin notes the daunting task for a State which seeks to apply case-by-case examination to the complex range of situations in civil wars, and argues in favour of limiting the use of the refugee definition. ${ }^{33}$ However, greater agreement on the use of the definition and a simplified test would be an advantage for the State concerned about the progressive realization of human rights. Moreover, States should not object to including in their policy and practice on asylum those persons who, for the most part, they do not expel anyway. The clarification should take into account those whose non-derogable rights would be at risk upon return and those facing return to a State at war, unable or unwilling to uphold their basic rights.

Asylum granting requires relatively simple administrative processes. An initial administrative decision could include consideration of the rights at issue. A stronger, more formal appeal procedure for negative decisions could satisfy the State's obligation to provide an effective remedy before expulsion. In a properly-run asylum procedure, the rigorous and more costly appeal procedures would apply to the minority of asylum-seekers turned down in the first instance.

Others have suggested a need for clarified substantive and procedural aspects of the 1951 Geneva Convention approach to asylum granting. The procedural requirements proposed by the European Consultation on Refugees and Exiles (ECRE), for example, would conform with article 14 of the Covenant on Civil and Political Rights. ${ }^{34}$ However, ECRE's proposal that the UNHCR or an independent commission have the right to give opinions on a manifestly unfounded case is inadequate. ${ }^{35}$ Some cases screened out as having no credible basis for a refugee claim in the Canadian procedure have been unsuccessfully appealed by both Amnesty Interna-

\footnotetext{
35 See Martin, above note 3.

34 European' Consultation on Refugees and Exiles, 'Fair and Efficient Procedures for Determining Refugee Status: A Proposal,' 3 IJRL 112 (1991).

93 Ibid, p. 118 (item 1.2).
} 
tional and the UNHCR. The Dutch Advisory Committee on Human Rights and Foreign Policy has recently recommended that the Foreign Affairs Minister harmonize the substance of asylum law and policy: 'It is essential that an international body be charged with monitoring the interpretation and application of asylum law and policy ...36 The Committee flags for clarification the issue of risk, rather than actual persecution; the concept of refugee sur place; the notion of Republikftucht; the threat of punishment for refusal to perform military service; limits on transfer to a first asylum country; and other areas of discretionary power.

An independent committee to ensure consistent application of a clarified 1951 Convention could be advantageous to States. Claimants could be more easily transferred among signatory States if there was objective evidence that a receiving State was both willing and able in practice to fulfil its obligations under the Convention. Persons facing a substantially similar asylum procedure in a State determined to be honouring the treaty would not face any serious deprivation of security of the person in the transfer. They would likely not object.

36 Advisory Committee on Human Rights and Foreign Policy (Netherlands), 'Harmonization of Asylum Law in Western Europe,'Advisory Report 10 (1991), P.O. Box 20061, 2500 EB The Hague.

\section{Résumé}

Le présent article examine la façon dont un État peut se servir de l'octroi de l'asile comme d'un moyen de s'acquitter de ses obligations relatives à la protection. On y étudic la nature et la substance de l'asile. Les pratiques actuelles en matière d'octroi du statut de réfugié, déterminées par la convention de Genève de 1951, sont compatibles en grande partie avec la nature et la substance de l'octroi de l'asile. Toutefois, des manquements graves aux obligations relatives au traitement des étrangers sur le territoire des États se produisent parfois pendant que les autorités sont en train de choisir entre l'octroi de l'asile et l'expulsion. L'article examine également les obligations-précisées dans les traités conclus entre différents États-qui régissent l'expulsion des gens et leur déportation vers un autre État. En général, les États remplissent ces obligations, mais dans certains cas ils ne respectent pas les obligations relatives au traitement des gens avant leur expulsion, ce qui donne lieu à des violations persistantes des droits de la personne. L'article compare l'asile avec les autres mécanismes élaborés par des Etats et destinés à tenir compte des obligations qui limitent ou conditionnent le droit d'expulsion. En conclusion, l'article signale quelques avantages éventuels d'un système plus lucide et plus cohérent d'octroi de l'asile et examine, à titre d'exemple, le rôle de l'asile au Canada et aux États-Unis.

\section{Resumen}

Este documento explora el potencial de otorgar asilo como un medio para cumplir las obligaciones de protección de un estado. La naturaleza y contenido del asilo son examinados. Las prácticas actuales para otorgar la condición de refugiado bajo la 
definición de la Convención de Ginebra de 1951 satisfacen en gran medida la naturaleza y contenido del otorgamiento de asilo. Sin embargo, ocurren serias violaciones de las obligaciones que conciernan al trato de extranjeros en territorios de estados, mientras se resuelven asuntos de asilo o expulsión. Las obligaciones contractuales de los estados respecto a la expulsión o transferencia de personas a otro estado son examinadas. Estas obligaciones son cumplidas por una mayoría, pero el no cumplir con las obligaciones resulta para algunas personas en una violación continua de derechos humanos elementales. El asilo es comparado con otras respuestas del estado a las obligaciones que calificar o condicionan el poder de expulsión. El documento sugiere beneficios potenciales que podrían surgir de una claridad y mayor coherencia en el otorgamiento de asilo, usando las situaciones particulares de Canadá y los Estados Unidos para ilustrar el rol que el asilo podria desempeñar. 